DOI https://doi.org/10.30525/978-9934-588-80-8-2.22

\title{
PARTICULARITIES OF MEDIA EDUCATION METODOLOGY FOR STUDENTS IN THE UNITED STATES OF AMERICA
}

\author{
Prykhodkina N. O. \\ Candidate of Pedagogical Sciences, Associate Professor, \\ Professor at the Department of pedagogy, \\ administration and special education \\ State higher educational institution "University of educational \\ management» of the National Academy of Educational Science of Ukraine \\ Kyiv, Ukraine
}

The problem of media education is being studied widely in the world. In particular, researchers on this issue in Canada include $\mathrm{K}$. Worsnop, B. Duncan, J. Piet, A. Caron, and others. C. Bazalgette, D. Buckingham, E. Hurt et al. in the United Kingdom, J. Gerbner, R. Kubey, R. Hobbs et al. in Australia - B. Macmahon, R. Quin et. al.

American media educators, both scientists and practitioners, draw on the theoretical concepts of L. Masterman [4], R. Hobbs [2], and the works of the famous Canadian scientist M. Mcluhan, who authored the world's first media education curriculum (1959). The author's theoretical writings influenced the process of media education in the United States.

Media educators in the United States follow different theoretical concepts of media and media education. There are American variants of «injection» and «practical» theory of media education, media education as a source of «satisfaction of needs» and critical thinking formation.

In 1996, American media educator D.Leveranz formulated the following requirements for students' knowledge and skills in media education (a kind of media education standard), according to which students must:

- have access to print, visual and electronic media for different purposes;

- master the media education terminology;

- understand that all media texts contain «messages»;

- be able to «decode» and analyze (based on the "critical analysis») media texts in a historical, social and cultural context, while understanding the relationship between the audience, the media and the surrounding reality;

- be able to create their own different media texts, discuss their own media, as well as media texts created by other people based on the acquired knowledge [3, p. 96].

Media education methodology:

- related to the study of various school subjects (history, art, English language and literature, ecology, etc.); 
- based on the study of key concepts of media education (category, language, agency, technology, audience, representation, etc.);

- based on the study of certain thematic sections connected with the process of media texts' creation, study of their species and genre features, structure and characteristics, ideas, functioning in society, etc.;

- based on concentrated media research;

- makes extensive usage of traditional forms of teaching, such as lessons, excursions, independent work, electives, with preference for practical and seminar exercises: usage of media technologies, effective using of problem, heuristic, research methods, often relying on play assignments, collaboration in groups and group discussions, additional material, experimentation.

The American educational system as a whole has always relied on a wide range of practical tasks and exercises. K.Tyner argues that media education can be conditionally divided into two parts similar to reading (viewing, audition) and writing (creation, speech). In media education, these two parts are called analysis and practice, although each contains an assumption about the appropriate content, knowledge and skills» [5, p. 8].

According to A. Fedorov, American media educators rightly hold the view that media education is more efficient if it involves both analysis of media texts and their production: students learn the basic principles of audio recording, visual composition. Each lesson ends with the stage of creation of its own media text, for example, «anti-advertising», parody, school news, short documentary film, etc. [1].

The Language Arts discipline (verbal) is the basis for the integration of media education most commonly. In addition to traditional tasks, such as comparing literary primary source and its adaptation, American educators teach students to identify patterns of representation of certain groups of people in different media texts (recognize gender, ethnic, social stereotypes), analyse print and video advertisements, identify the techniques and choose them according to the target audience. The class discusses the legal and ethical aspects of reality shows, learns to interpret films in terms of the social and moral attitudes they convey, analyzes media stereotypes, political cartoons in newspapers and magazines, pre-electoral political advertising, news, popular songs and TV shows.

Within the framework of the discipline «Mathematics» PBS methodists offer the following media education problems: to investigate hidden syllogisms in advertising, to calculate the percentage of advertising messages in various media texts, to explore the controversial economic relationship between the tobacco/alcohol industry and sport. In the course of lessons in environmental science, images of scientists and natural disasters in media texts are studied, the reliability of the product's advertised indicators is tested, knowledge of physical/chemical laws is tested, and why a process or phenomenon shown in advertising is (not) possible. 
In the classes «Social Science» the methods of media manipulation used by politicians and terrorists, news coverage by various media, problems of interaction of media and audience are analyzed.

During studying the subject «Health», students consider topics related to advertising of food, cigarettes, alcohol and drugs, gender images in the media, sexualized advertising messages and TV shows. We're also looking at ways to solve problems, and we're showing them in TV programs, movies, commercials - buying anything, violence, lying, drugs and so on. Students should offer an alternative solution using positive problemsolving strategies.

So, American educators have developed a wide range of techniques to teach key concepts of media education and have developed a fairly rich experience of integrating media education elements in different academic disciplines. In recent years, practical media education namely the creation of own media texts using the digital cameras, cameras, computer programs, etc., is coming to the fore.

\section{References:}

1. Федоров А.В., Новикова А.А., Колесниченко В.Л., Каруна И.А. Медиаобразование в США, Канаде и Великобритании. Таганрог: Изд-во Кучма, 2007. 256 с. URL: https://www.researchgate.net/publication/ 278518033_Mediaobrazovanie_v_SSA_Kanade_i_Velikobritanii

2. Hobbs R. (2004). Media Literacy, General Semantics, and K-12 Education. URL: https://pdfs.semanticscholar.org/124c/a0a1757771232 252dc326a1d982362b069ee.pdf?_ga=2.90711379.832069154.1599309990299729537.1599309990

3. Leveranz, D. \& Tyner, K. (1996). What is media literacy? Two leading proponents offer an overview. Media Spectrum, 23(1), 10.

4. Masterman, L. (1997). A Rational for Media Education. In: Kubey R. (Ed.). Media Literacy in the Information Age. New Brunswick (U.S.A.) and London (U.K.): Transaction Publishers, pp. 15-68.

5. Tyner, K. (1998). Literacy in the Digital World: Teaching and Learning in the Age of Information. Mahwan, NJ: Lawrence Erlbaum Associates, $291 \mathrm{p}$. 